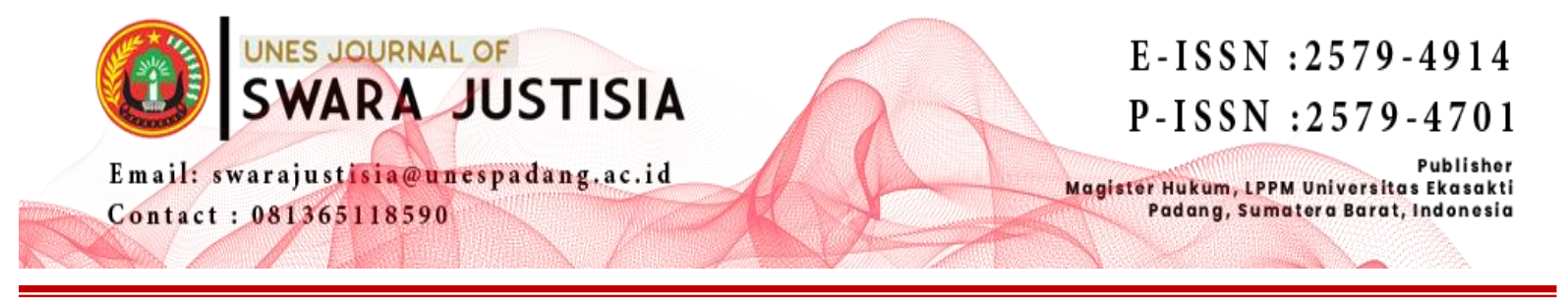

\title{
IMPLEMENTASI NILAI KEBANGSAAN BHINNEKA TUNGGAL IKA DALAM PENINGKATAN PELAYANAN PUBLIK
}

\author{
Desirizta Sari Steviani \\ Program Magister Ilmu Hukum, Universitas Ekasakti, Padang, Indonesia \\ Email: jsaridesirizta@gmail.com
}

\begin{abstract}
National values are the values inherent in the Indonesian nation which are used as guidelines for living in society, nation and state. There are four national values which serve as the consensus of national life, namely Pancasila, the 1945 Constitution, Sensanti Bhinneka Tunggal Ika and the Unitary State of the Republic of Indonesia. Public service is part of providing services to the community. Where the provision of public services should uphold national values. Public Service is an activity or a series of activities in order to fulfill service needs in accordance with statutory regulations for every citizen and resident for goods, services and or administrative services provided by public service providers. National values have the meaning of values that are contained. The value of Sesanti Bhinneka Tunggal Ika has three values, namely the value of tolerance, the value of justice and the value of mutual cooperation. These three values, if implemented, can improve public services.
\end{abstract}

Keywords: National Value, Bhinneka Tunggal Ika, Public Service

\begin{abstract}
ABSTRAK
Nilai-nilai kebangsaan adalah nilai-nilai yang melekat pada bangsa Indonesia yang dijadikan sebagai pedoman hidup dalam bermasyarakat, berbangsa dan bernegara. Ada empat nilainilaikebangsaan yang dijadikan sebagai konsensus hidup berbangsa yaitu Pancasila, Undangundang Dasar 1945, Sensanti Bhinneka Tunggal Ika dan Negara Kesatuan Republik Indonesia. Pelayanan publik merupakan bahagian dari pemberian pelayanan kepada masyarakat. Dimana dalam melakukan pemberian pelayanan publik hendaknya menjunjung nilai-nilai kebangsaan. Pelayanan Publik merupakan kegiatan atau rangkaian kegiatan dalam rangka pemenuhan kebutuhan pelayanan sesuai dengan peraturan perundang-undangan bagi setiap warga negara dan penduduk atas barang, jasa, dan atau pelayanan administrative yang disediakan oleh penyelenggara pelayanan publik. Nilai-nilai kebangsaan mempunyai makna nilai yang terkandung. Nilai Sesanti Bhinneka Tunggal Ika mempunyai tiga nilai yaitu nilai toleransi, nilai keadilan dan nilai gontong royong. Ketiga nilai ini jika diimplementasikan dapat meningkatkan pelayanan publik.
\end{abstract}

Kata Kunci: Nilai Kebangsaan, Bhinneka Tunggal Ika, Pelayanan Publik

\section{PENDAHULUAN}

Bangsa Indonesia adalah bangsa yang majemuk terdiri dari bermacam suku bangsa, budaya, ras, agama dan luas wilayah yang sangat luas. Dalam melaksanakan kehidupan 
berbangsa, bangsa Indonesia mempuyai pondasi yang dikenal dengan Pilar-pilar Kebangsaan atau Empat Konsensus Dasar Berbangsa. Empat Konsensus Dasar Berbangsa merupakan hakekat nilai-nilai kebangsaan. Nilai-nilai kebangsaan pada hakekatnya adalah nilai yang disepakati dan dipandang baik, yang melekat pada diri setiap warga negara Indonesia berupa norma-norma dan etika kebaikan yang terkandung dan menjadi ciri kepribadian bangsa Indonesia yang bersumber dari nilai-nilai Pancasila, Undang-undang Dasar 1945 (UUD 45), Negara Kesatuan Republik Indonesia (NKRI) dan Bhinneka Tunggal Ika. Nilai-nilai kebangsaan dapat diimplementasikan dalam melakukan pelayanan publik oleh pemerintah.

Pemerintahan adalah bahagian dari sebuah sistem yang ada dalam sebuah negara. Setiap pemerintahan harus memiliki kepentingan yang melayani publik, sebagaimana amanat pembukaan UUD 45 yang memuat bahwa pemerintah negara Indonesia melindungi segenap bangsa Indonesia dan seluruh tumpah darah Indonesia dan untuk memajukan kesejahteraan umum, mencerdaskan kehidupan berbangsa dan ikut melaksanakan ketertiban dunia. Pelayanan Publik tertuang dalam Undang-undang Nomor 25 Tahun 2009, dijelaskan bahwa pelayanan publik adalah kegiatan atau rangkaian kegiatan dalam rangka pemenuhan kebutuhan pelayanan sesuai dengan peraturan perundang-undangan bagi setiap warga negara dan penduduk atas barang, jasa, dan atau pelayanan adninistratif yang disediakan oleh penyelenggara pelayanan publik dengan tujuan terwujudnya sistem penyelenggaraan pelayanan publik yang layak sesuai dengan asas-asas umum pemerintahan dan korporasi yang baik.

Namun kondisinya saat ini dalam penyelenggaraan pelayanan publik, pelayanan publik masih memiliki berbagai kelemahan. Pertama kelemahan dalam penyelenggaraan pelayanan publik diantaranya kurang responsif, kurang informatif, kurang accessible, kurang koordinasi, birokratis, kurang mau mendengar keluhan/saran/aspirasi masyarakat dan inefisien (Wahid, Ali Abdul, 2017:53). Kedua kelemahan dalam aspek sumber daya manusia, kelemahan utamanya adalah berkaitan dengan profesionalisme, kompetensi, empaty dan etika (Wahid, Ali Abdul, 2017:53). Jika dilihat dari Indeks Pelayanan Publik (IPP) yang dikeluarkan oleh Kementerian Pendayagunaan Aparatur Negara dan Reformasi Birokrasi pada tanggal 24 Juni 2020, bahwa besar IPP yaitu 3,43 untuk Pemerintah Daerah, 3,83 untuk Kementerian/Lembaga dan secara Nasional IPP sebesar 3,63. Dimana range indeks 3,013,50 mempunyai makna bahwa pelayanan publik bernilai B- (Baik Dengan Catatan). Indeks Pelayanan Publik ini mengukur 6 indikator yang terdiri dari kebijakan pelayanan, profesionalisme Sumber Daya Manusia, sarana prasarana, Sistem Informasi Pelayanan Publik (SIPP), konsultasi dan pengaduan serta Inovasi Pelayanan.

Dalam melaksanakan penyelenggaraan pelayanan publik dibutuhkan pelayanan yang prima. Untuk dapat mewujudkan pelayanan prima maka dibutuhkan internalisasi atau implementasi nilai-nilai kebangsaan dalam pelayanan publik. Dari empat nilai-nilai kebangsaan yang bersumber dari Pancasila, UUD 45, NKRI dan Bhinneka Tunggal Ika, untuk saat ini penulis membahas nilai kebangsaan yang bersumber dari Bhinneka Tunggal Ika. Pembahasan dalam penulisan ini adalah mengenai bagaimana implementasi nilai kebangsaan Bhinneka Tunggal Ika dalam peningkatan pelayanan Publik. 


\section{PEMBAHASAN}

\section{A. Nilai Kebangsaan Bhinneka Tunggal Ika}

Nilai yang melekat pada diri setiap warga negara atau norma kebaikan yang menjadi ciri kepribadian bangsa Indonesia merupakan makna dari nilai-nilai kebangsaan. Ada empat sumber nilai-nilai kebangsaan, Pertama Pancasila, Kedua Undang-undang Dasar 1945, Ketiga Bhinneka Tunggal Ika dan Keempat Negara Kesatuan Republik Indonesia. Keempat sumber nilai-nilai kebangsaan ini merupakan sebagai pedoman hidup dalam berbangsa dan bernegara. Namun untuk saat ini yang akan dibahas adalah nilai ketiga yaitu Bhinneka Tunggal Ika. Bhinneka Tunggal Ika diungkapkan pertama kali oleh mPu Tantular, penganut Budha Tantrayana, Pujangga Angung Kerajaan Majapahit pada masa pemerintahan Raja Hayamwuruk (Tahun 1350-1389). Bhinneka Tunggal Ika lebih dikenal dengan sesanti atau semboyan Bhinneka Tunggal Ika. Sesanti tersebut terdapat dalam karyanya; Kakawin Sutasoma, Pupuh (Bab) 139, Bait 5, yang berbunyi "Bhinna ika tunggal ika, tan hana dharma mangrva" yang artinya "Berbeda-beda itu satu itu, tak ada pengabdian yang mendua" Isi Kakawin Sutasoma diantaranya berisi wejangan cara mengatasi segala bentuk perbedaan agama (antara Shiwa/Hindhu dan Budha waktu itu) yang dirasakan sangat rentan terhadap terjadinya konflik pada masa Majapahit.

Sesanti dijadikan prinsip kehidupan dalam pemerintahan kerajaan Majapahit, mengantisipasi keaneka-ragaman agama yang dipeluk rakyat Majapahit saat itu, untuk menciptakan kedamaian dalam perbedaan kehidupan beragama, yaitu Hindhu dan Budha Meskipun berbeda agama tetapi mereka tetap satu dalam pengabdian Sesanti Bhinneka Tunggal Ika mengacu bahasa Sanskrit, hampir sama dengan semboyan e Pluribus Unum, semboyan Bangsa Amerika Serikat yang maknanya diversity in unity, perbedaan dalam kesatuan. Diungkap di abad ke XVIII, empat abad setelah Mpu Tantular mengemukakan Sesanti Bhinneka Tunggal Ika. Muhammad Yamin, mengusulkan Bhinneka Tunggal Ika dijadikan Semboyan bagi Negara Kesatuan Republik Indonesia. Tahun 1951, 600 tahun setelah diungkap oleh Mpu Tantular, Bhinneka Tunggal Ika ditetapkan sebagai semboyan resmi Negara Republik Indonesia melalui Peraturan Pemerintah (PP) No.66 tahun 1951. Kata "bhinna ika," kemudian dirangkai menjadi satu kata "bhinneka".

Sesanti Bhinneka Tunggal Ika adalah rangkuman ungkapan jiwa dan semangat bangsa Indonesia yang menjunjung tinggi kesatuan dan persatuan sebagai bangsa yang terdiri dari beragam suku, agama, ras dan golongan. Selain dari itu Sesanti Bhinneka Tunggal Ika juga merupakan semboyan untuk menata, mengatur, mengharmoniskan dan menghormati kehidupan bermasyarakat, berbangsa dan bernegara. Sesanti Bhinneka Tunggal Ika juga merupakan sarana untuk memberikan keleluasaan (kebebasan) bagi semua warga bangsa untuk mengembangkan tata kehidupan sesuai dengan lingkungan masyarakatnya demi memperkuat persatuan bangsa dan hubungan antar warga yang harmonis.

Nilai kebangsaan yang bersumber dari Sesanti Bhinneka Tunggal Ika meliputi tiga nilai yaitu:

1. Nilai Toleransi, merupakan sikap mau memahami orang lain demi berlangsungnya komunikasi secara baik dan menghargai pendapat atau posisi orang lain disekitar kita. Nilai toleransi juga dapat berupa hubungan yang baik, hierarkis, senioritas, status, 
keharmonisan dalam kelompok, keamanan, kesejahteraan keluarga, sopan santun, rendah hati, rela berkorban dan pemurah (Jenny, Njaju dkk, 2020).

2. Nilai Keadilan, merupakan sikap tidak memihak dan tidak mengelompokan antar golongan atau memberikan perlakuan yang sama kepada semua kalangan. Nilai keadilan meliputi rasa keadilan sosial, rasa keadilan politik, pemerataan ekonomi, keterbukaan, keseimbangan, persamaan, nonkontradiksi, pemberian hak kepada pihak yang berhak, sikap hormat dan bijaksana (Jenny, Njaju dkk, 2020)

3. Nilai Gotong Royong, mempunyai makna memikul beban secara Bersama-sama. Tujuan dari gontong royong adalah meringankan beban sesamanya atau guna mewujudkan kepentingan bersama. Gontong royong dapat ditunjukan dengan sikap peduli, persamaan derajat, persatuan, kerjasama, tata kehidupan, sederhana, demokrasi, berpartisipasi, membantu dan ketergantungan. (Jenny, Njaju dkk, 2020)

Nilai-nilai kebangsaan yang bersumber dari Sesanti Bhinneka Tunggal Ika dapat di implementasikan dalam kehidupan sehari-hari baik dalam kehidupan bermasyarakat, berbangsa dan bernegara. Nilai-nilai ini dapat diimplementasikan dengan berbagai macam metode seperti dialog, pendidikan, seni budanya, reformasi hukum, penyediaan pelayanan hukum, persaudaraan, tanggungjawab dan kerja keras. Nilai kebangsaan adalah falsafah bagi kehidupan bermasyarakat, berbangsa dan bernegara.

\section{B. Pelayanan Publik}

Pelayanan publik tertuang dalam Undang-undang Nomor 25 Tahun 2009. Pelayanan Publik merupakan kegiatan atau rangkaian kegiatan dalam rangka pemenuhan kebutuhan pelayanan sesuai dengan peraturan perundang-undangan bagi setiap warga negara dan penduduk atas barang, jasa dan atau pelayanan administratif yang disediakan oleh penyelenggara pelayanan publik. Pelayanan publik diselenggarakan oleh institusi negara, korporasi dan Lembaga. Dalam penyelenggaraannya pelayanan publik dilaksanakan oleh pelaksana pelayananan publik yang terdiri dari pejabat, pegawai, petugas dan setiap orang yang bekerja didalam organisasi penyelenggara yang bertugas melaksanakan tindakan atau serangkaian Tindakan pelayanan publik.

Menurut Undang-undang 25 Tahun 2009 tentang Pelayanan Publik, pelayananan publik bertujuan untuk:

1. Terwujudnya batasan dan hubungan yang jelas tentang hak, tanggung jawab, kewajiban, dan kewenangan seluruh pihak yang terkait dengan penyelenggaraan pelayanan publik;

2. Terwujudnya sistem penyelenggaraan pelayanan publik yang layak sesuai dengan asas-asas umum pemerintahan dan korporasi yang baik;

3. Terpenuhinya penyelenggaraan pelayanan publik sesuai dengan peraturan perundangundangan; dan

4. Terwujudnya perlindungan dan kepastian hukum bagi masyarakat dalam penyelenggaraan pelayanan publik.

Penyelenggaraan pelayanan publik berdasarkan asas kepentingan umum, kepastian hukum, kesamaan hak, keseimbangan hak dan kewajiban, keprofesionalan, partisipatif, persamaan perlakuan/tidak diskriminatif, keterbukaan, akuntabilitas, fasilitas dan perlakuan khusus bagi kelompok rentan, ketepatan waktu dan kecepatan, kemudahan 
dan keterjangkauan. Pelayanan publik mempunyai ruang lingkup dalam (i) pelayanan barang publik dan jasa publik seperti pengadaan barang dan jasa oleh instansi pemerintah (ii) pelayanan administratif yang dilakukan oleh pemerintah atau instansi pemerintah. Dalam melaksanakan pelayanan publik, menurut ketentuan Pasal 15 Undang- Undang No. 25 tahun 2009 penyelenggara berkewajiban:

1. Menyusun dan menetapkan standar pelayanan;

2. Menyusun, menetapkan, dan memublikasikan maklumat pelayanan;

3. Menempatkan pelaksana yang kompeten;

4. Menyediakan sarana, prasarana, dan/atau fasilitas pelayanan publik yang mendukung terciptanya iklim pelayanan yang memadai;

5. Memberikan pelayanan yang berkualitas sesuai dengan asas penyelenggaraan pelayanan publik;

6. Melaksanakan pelayanan sesuai dengan standard pelayanan;

7. Berpartisipasi aktif dan mematuhi peraturan perundang-undangan yang terkait dengan penyelenggaraan pelayanan publik;

8. Memberikan pertanggungjawaban terhadap pelayanan yang diselenggarakan;

9. Membantu masyarakat dalam memahami hak dan tanggung jawabnya;

10. Bertanggung jawab dalam pengelolaan organisasi penyelenggara pelayanan publik;

11. Memberikan pertanggungjawaban sesuai dengan hukum yang berlaku apabila mengundurkan diri atau melepaskan tanggung jawab atas posisi atau jabatan; dan

12. Memenuhi panggilan atau mewakili organisasi untuk hadir atau melaksanakan perintah suatu tindakan hukum atas permintaan pejabat yang berwenang dari lembaga negara atau instansi pemerintah yang berhak, berwenang, dan sah sesuai dengan peraturan perundang- undangan.

Adapun asas-asas pelayanan publik menurut Pasal 4 Undang-Undang No 25

Tahun 2009 adalah:

1. Kepentingan umum, yaitu pemberian pelayanan tidak boleh mengutamakan kepentingan pribadi dan/atau golongan.

2. Kepastian hukum, yaitu Jaminan terwujudnya hak dan kewajiban dalam penyelenggaraan pelayanan.

3. Kesamaan hak, yaitu Pemberian pelayanan tidak membedakan suku, ras, agama, golongan, gender, dan status ekonomi.

4. Keseimbangan hak dan kewajiban, yaitu Pemenuhan hak harus sebanding dengan kewajiban yang harus dilaksanakan, baik oleh pemberi maupun penerima pelayanan.

5. Keprofesionalan, yaitu Pelaksana pelayanan harus memiliki kompetensi yang sesuai dengan bidang tugas.

6. Partisipatif, yaitu peningkatan peran serta masyarakat dalam penyelenggaraan pelayanan dengan memperhatikan aspirasi, kebutuhan, dan harapan masyarakat.

7. Persamaan perlakuan/tidak diskriminatif, yaitu setiap warga negara berhak memperoleh pelayanan yang adil.

8. Keterbukaan, yaitu setiap penerima pelayanan dapat dengan mudah mengakses dan memperoleh informasi mengenai pelayanan yang diinginkan.

9. Akuntabilitas, yaitu proses penyelenggaraan pelayanan harus dapat dipertanggungjawabkan sesuai dengan ketentuan peraturan perundang-undangan 
10. Fasilitas dan perlakuan khusus bagi kelompok rentan, yaitu pemberian kemudahan terhadap kelompok rentan sehingga tercipta keadilan dalam pelayanan.

11. Ketepatan waktu, yaitu penyelesaian setiap jenis pelayanan dilakukan tepat waktu sesuai dengan standar pelayanan.

12. Kecepatan, kemudahan, dan keterjangkauan, yaitu setiap jenis pelayanan dilakukan secara cepat, mudah, dan terjangkau.

Pelaksana dalam menyelenggarakan pelayanan publik menurut Pasal 34 UndangUndang No. 25 tahun 2009 tentang Pelayanan Publik, harus berperilaku sebagai berikut:

1. Adil dan tidak diskriminatif;

2. Cermat;

3. Santun dan ramah;

4. Tegas, andal, dan tidak memberikan putusan yang berlarut-larut;

5. Profesional;

6. Tidak mempersulit;

7. Patuh pada perintah atasan yang sah dan wajar;

8. Menjunjung tinggi nilai-nilai akuntabilitas dan integritas institusi penyelenggara;

9. Tidak membocorkan informasi atau dokumen yang wajib dirahasrakan sesuai dengan peraturan perundang-undangan;

10. Terbuka dan mengambil langkah yang tepat untuk menghindari benturan kepentingan;

11. Tidak menyalahgunakan sarana dan prasarana serta fasilitas pelayanan publik;

12. Tidak memberikan informasi yang salah atau menyesatkan dalam menanggapi permintaan informasi serta proaktif dalam memenuhi kepentingan masyarakat;

13. Tidak menyalahgunakan informasi, jabatan, dan/atau kewenangan yang dimiliki;

14. Sesuai dengan kepantasan; dan

15. Tidak menyimpang dari prosedur.

Penyelenggara pelayanan publik diharuskan memberikan pelayanan publik yang prima (excellent). Pelayanan publik yang prima adalah pelayanan yang diberikan sesuai dengan asas pelayanan publik. Kualitas pelayanan publik terlihat dari sikap atau cara melayani. Menurut Triguno (1997:78) pelayanan/ penyampaian terbaik adalah melayani setiap saat, secara tepat dan memuaskan, berlaku sopan, ramah dan menolong serta professional dan mampu.

\section{Implementasi Nilai Kebangsaan Bhinneka Tunggal Ika Dalam Peningkatan Pelayanan Publik}

Dalam pelaksanaan penyelenggaraan pelayanan publik masih banyak terjadi kelemahan antara lain:

1. Kurang responsif. Kurangnya respon penyelenggaran pelayanan publik didalam menghadapi berbagai keluhan, aspirasi, maupun harapan masyarakat.

2. Kurang informatif. Banyak informasi yang tidak tersampaikan kepada masyarakat atau lambat sampai kepada masyarakat.

3. Kurang accessible. Sulitnya akses masyarakat untuk menjangkau pelayanan public.

4. Kurang koordinasi. Sering terjadi tumpeng tindih atauun pertentangan antara satu instansi pelayanan dengan pelayanan lainnya. 
5. Birokratis. Panjangnya proses birokrasi dalam pelayanan yang harus melewati berbagai macam level sehingga penyelesaian pelayanan publik menjadi lama.

6. Kurang mau mendengar keluhan/saran/aspirasi masyarakat. Penyelenggara pelayanan publik kurang kemauan untuk mendengarkan keluhan dari masyarakat yang mengakibatkan pelayanan publik di berubah dari waktu ke waktu.

7. Inefisien. Persyaratan dalam memberikan pelayanan sering tidak relevan dengan pelayanan yang diberikan.

Dari perspektif good governance ada beberapa model pelayanan public yang dapat digunakan untuk mengatasi pelayanan publik seperti Model Citizens Charter (Kontrak Pelayanan), Model Know Your Costumers (Model KYC) dan Model MGovernment (m-Gov). Namun untuk tulisan ini penulis membahas dari sudut pandang nilai-nilai kebangsaan. Sebagai bangsa yang besar yang melayani banyak masyarakat, penyelenggara pelayanan publik hendaknya menginternaliasasi nilai-nilai kebangsaan dalam melaksanakan pelayanan publik.

Implementasi nilai kebangsaan Bhinneka Tunggal Ika dalam peningkatan pelayanan publik dapat dilakukan sebagai berikut:

1. Nilai Toleransi. Undang-undang pelayanan publik telah mengatur tentang asas- asas pelayanan publik dan etika dalam memberikan pelayanan. Pelayanan yang kurang responsif dan informatif seharusnya tidak dapat terjadi jika pemberi pelayanan menyadari bahwa kita adalah pelayan bagi masyarakat dengan menjalin hubungan baik, rendah hati dan rela berkorban. Adanya sikap yang responsif dengan indikator; merespon keinginan masyarakat, melakukan pelayanan dengan cepat, tepat, cermat dan akurat.

2. Nilai Keadilan. Dalam pemberian pelayanan publik hendaknya penyelenggaraan pelayananan publik didasari dengan sikap rasa keterbukaan, hormat dan memberikan akses informasi seluas-luasnya kepada penerima pelayanan publik. Indikator nilai keadilan adalah mendahulukan kepentingan pelayanan publik dari pada kepentingan pribadi, tidak diskriminatif dalam melakukan pelayanan dengan tidak membedabedakan pelayanan yang diberikan kepada penerima pelayanan dan menghargai dalam memberikan pelayanan.

3. Nilai Gontong Royong. Pelayanan publik dapat berjalan dengan baik sesuai nilai-nilai kebangsaan, jika pemberi pelayanan publik menyadari bahwa mereka bahagian dari bangsa dan negara yang harus mempunyai empaty dalam melakukan pelayanan. Melakukan pelayanan publik dengan sikap empaty, tidak mempersulit, ramah, sopan, santun dan sesuai dengan kepantasan.

Nilai-nilai kebangsaan Bhinneka Tunggal Ika dibutuhkan dalam melakukan peningkatan pelayanan publik dengan tidak membeda siapa yang akan dilayani serta menyadari bahwa pelayanan publik merupakan bahagian dari kehidupan berbangsan dan bernegara. Dengan menyadari dan mengimplementasikan nilai-nilai kebangsaan maka akan mengurangi permasalahan yang ada dalam pelaksanaan pelayanan publik. 


\section{KESIMPULAN}

Bangsa Indonesia adalah bangsa yang majemuk dan besar yang terdiri dari berbagai suku, budaya, rasa dan golongan serta luas wilayah yang sangat luas. Dimana dalam kehidupan berbangsa dan bernegara dibutuhkan nilai-nilai kehidupan. Sensanti Bhinneka Tunggal Ika merupakan pernyaatan jiwa dan semangat bangsa Indonesia dalam keberagaman. Nilai-nilai dalam sesanti Bhinneka Tunggal Ika dapat di implementasikan dalam meningkatkan pelayanan publik untuk mencapai pelayanan prima (servise excellent).

\section{DAFTAR PUSTAKA}

Hardjatno, Prof. Dr. Njaju Jenny M.T dkk. "Materi Pokok Sub Bidang Studi Bhinneka Tunggal IKa”. LEMHANNAS, Jakarta, 2020.

Latra, I Wayan. "Nilai-nilai Bhinneka Tunggal Ika Dalam Kehidupan Bermasyarakat, Berbangsa dan Bernegara”. UPT Pendidikan Pembangunan Karakter Bangsa, Denpasar, 2018.

Mahsyar, Abdul. "Masalah Pelayanan Publik di Indonesia Dalam Perspektif Administrasi Publik”. Jurnal Otoritas Vol I, Nomor 2, Oktober 2011,

Nurdin, Dr. Drs Ismail. “Kualitas Pelayanan Publik (Perilaku Aparatur dan Komunikasi Birokrasi Dalam Pelayanan Publik)”. Media Sahabat Cendekia, Surabaya, 2019.

Nuriyanto. "Penyelenggaraan Pelayanan Publik di Indonesia, Sudahkah Berlandasan Konsep Welfare State”. Jurnal Konstitusi, Volume 11, Nomor 3, September 2014,

Wahid, Ali Abdul. "Reformasi Pelayanan Publik di Indonesia”. Jurnal TAPIs No.14 Vol.01 Januari-Juni 2017,

Undang-Undang Nomor 25 Tahun 2009 tentang Pelayanan Publik

Peraturan Menteri Pendayagunaan Aparatur Negara dan Reformasi Birokrasi Republik Indonesia Nomor 17 tahun 2017 tentang Pedoman Penilaian Kinerja Unit Penyelenggara Pelayanan Publik

https://www.menpan.go.id/site/pelayanan-publik/indeks-pelayanan-publik-ipp 